\title{
CDISC SEND Restraint Mode Response Terminology
}

National Cancer Institute

\section{Source}

National Cancer Institute. CDISC SEND Restraint Mode Response Terminology. NCI

Thesaurus. Code C158123.

Terminology associated with the restraint mode response codelist of the Clinical Data Interchange Standards Consortium (CDISC) Standard for the Exchange of Non-clinical Data (SEND). 